\title{
A study of correlation of plasma fibrinogen levels with glycemic status in type 2 Diabetes Mellitus patients
}

\author{
Pravinkumar Vijaykumar Ghongade ${ }^{1}$, Manisha Anantrao Atram ${ }^{1}$, \\ Vitaladevuni Balasubramanyam Shivkumar ${ }^{1}$ \\ ${ }^{\prime}$ Department of Pathology, Mahatma Gandhi Institute of Medical Sciences, Maharashtra, India
}

Keywords:

Complications; Glycated hemoglobin; Plasma fibrinogen; Type 2 diabetes mellitus;

\begin{abstract}
Background: Plasma fibrinogen is an indicator of inflammation and endothelial dysfunction has been described as an independent risk factor for cardiovascular morbidity in type 2 Diabetes mellitus patients. Poor glycemic control has been reported to be associated with hyperfibrinogenemia and its complications. This study was aimed to find a correlation of mean fibrinogen level with glycemic control in complicated and uncomplicated cases of Type 2 Diabetes mellitus.
\end{abstract}

Materials and Methods: One hundred eight known cases of Type 2 Diabetes mellitus aged $\geq 30$ were included in our study of which 39 cases were uncomplicated and 69 cases were complicated Diabetes mellitus. Hundred of non-diabetic age and sex-matched controls were analyzed. Blood samples were collected in Ethylenediaminetetraacetic acid and citrate bulb for estimation of HbAlc and plasma fibrinogen level respectively.

Results: Mean fibrinogen level in complicated Type 2 Diabetes mellitus was high $450.43 \pm 108.51 \mathrm{mg}$ / $\mathrm{dl}$ as compared to uncomplicated cases $372.30 \pm 123.78 \mathrm{mg} / \mathrm{dl}(\mathrm{p}=0.0001)$. Mean HbAlc in total Diabetes mellitus cases was $8.02 \pm 1.88 \mathrm{mg} / \mathrm{dl}$ with a range of $5.50-14.50 \mathrm{mg} / \mathrm{dl}$. A positive correlation was found between HbA1c and mean fibrinogen level $(r=0.782, p=0.001)$ in type 2 Diabetes mellitus. Duration of diabetes in years showed a significant correlation with mean fibrinogen levels $(r=0.295, p=0.002)$.

Conclusions: Plasma fibrinogen level was significantly associated with glycemic control (HbAlc) and duration of Diabetes mellitus in years. Thus, lowering plasma fibrinogen levels could be an important approach to the prevention of cardiovascular complications in diabetics.

\section{Correspondence:}

Dr. VB Shivkumar

Professor, Department of Pathology

Mahatma Gandhi Institute of Medical Sciences, Maharashtra, India ORCID ID: 0000-0002-9042- 9235

Email:shivkumar@mgims.ac.in

Received : May $1^{\text {st }} 2020 ;$ Accepted : September $22^{\text {nd }} 2020$

Citation: Ghongade PV, Atram MA, Shivkumar VB. A study of correlation of plasma fibrinogen levels with glycemic status in type 2 Diabetes Mellitus patients. J Pathol Nep 2020;10: :1746-50 DOI: 10.3126/jpn.v10i2.28706

Copyright: This is an open-access article distributed under the terms of the Creative Commons Attribution 4.0 International License, which permits unrestricted use, distribution, and reproduction in any medium, provided the original author and source are credited.

\section{INTRODUCTION}

Diabetes mellitus (DM) is a chronic metabolic disorder characterized by hyperglycemia and disturbances in carbohydrates, fats, and protein metabolism. ${ }^{1}$ Type $2 \mathrm{DM}$ which is characterized by peripheral insulin resistance accounts for more than $90 \%$ of the global diabetic population. 1 The global prevalence of DM in 2019 is estimated to be $9.3 \%$, increasing to $10.2 \%$ by $2030 .^{2}$

Also, the prevalence is higher in developed countries $(10.4 \%)$ and urban areas $(10.8 \%)$ than in developing countries $(4.0 \%)$ and rural (7.2\%) populations. ${ }^{2}$ 
$\mathrm{DM}$ is a hypercoagulable state with $75 \%$ of deaths due to cardiovascular diseases as a result of thrombotic complications. $^{3}$ Fibrinogen is an important constituent of the coagulation cascade and an important determinant of blood viscosity, platelet aggregation, and thrombus formation. Increased plasma levels of fibrinogen have been reported in patients of Type 2 DM. ${ }^{4}$. Plasma fibrinogen itself is determined by several modifiable and non-modifiable determinants like age, sex, smoking, hypertension, HbAlc, etc. So increased attention is needed to understand the disordered hemostatic mechanism in diabetes. ${ }^{5}$

Hence this study is aimed to evaluate the correlation of age, duration of type $2 \mathrm{DM}$ with plasma fibrinogen levels, and glycated hemoglobin levels in patients with type 2 DM for early detection, monitoring, and appropriate management to reduce morbidity and mortality associated with type 2 DM.

\section{MATERIALS AND METHODS}

This is a cross-sectional study conducted at the Department of Pathology of tertiary care rural hospital from 2016 to 2018. This study was approved by the Institutional Ethical Committee and written informed consent was taken from all the patients. One hundred eight patients of DM, aged $\geq 30$ years of either sex were included, of which 39 cases were without any complications and 69 cases had different microvascular and macrovascular complications. Clinical details of these patients along with socio-demographic data were recorded from the hospital information system. Hundred of non-diabetic age and sex-matched controls who did not have any chronic liver diseases, chronic kidney diseases, and any known coagulation disorder were selected. Appropriate control selection for the study was based on history, previous investigations were done in this hospital/outside, and also information from the medical record department.

Inclusion criteria were diagnosed cases of type 2 DM with or without related complications. The patients with a history of hypercoagulability, thromboembolism, inherited coagulation disorders, cancer, pregnancy, recent surgery, etc, and patients who were receiving standard anticoagulant treatment were excluded from the study. Venous blood samples of all the participants (patients and controls) were collected in Ethylenediaminetetraacetic acid and citrate bulb and were subjected for platelet count, fibrinogen level, and HbAlc. Fibrinogen level was estimated using the Clauss technique, with 'FIBROQUANT' test kit marketed by Tulip diagnostic on Behnk coagulometer. ${ }^{6} \mathrm{HbA} 1 \mathrm{c}$ assay was done by particle enhanced immunoturbidimetric Methodology.

Patient data were collected using a structural interview questionnaire and analyzed by the statistical package for social sciences (SPSS) program version 17. The Student's t-test was used to know the significant difference among the continuous variables between the 2 groups (DM type 2 patients in group 1 and controls in group 2). Pearson correlation (r) was done to assess the degree of association between variables in different groups. A p-value of $<0.05$ was considered statistically significant.

\section{RESULTS}

The study included 108 diagnosed patients of Type 2 DM of which $64(59.3 \%)$ were males and $44(40.7 \%)$ were females with a M: F ratio of 1.4:1. Analysis of clinical data and biochemical parameters using the t-test showed a significant correlation between variables such as age, duration of diabetes with $\mathrm{HbA1c}$, and fibrinogen levels in patients with type 2 DM with and without complications.

Of the total 108 patients, 39 cases were Type 2 DM without complication and 69 cases were with different DM complications. The mean age of patients for uncomplicated Type 2 DM was $53.58 \pm 11$.1years, for complicated DM was $57.85 \pm 11.33$ years, and for the control group mean age was $54.33 \pm 12.13$ years. Maximum patients of Type $2 \mathrm{DM}$ with complications were found in the age group of 61-70 years $(33.33 \%)$ followed by $51-60$ years $(30.43 \%)$.

Among 69 complicated cases of Type 2 DM, $13(21.67 \%)$ cases were with myocardial infarction (MI), 10 (14.49\%) cases with stroke, 11 cases (15.94\%) with neuropathy, 11 cases (15.94\%) with nephropathy, 14 cases (20.29\%) with retinopathy, 10 cases $(14.49 \%)$ with a gangrenous foot. The mean fibrinogen level in DM cases was found to be $422.22 \pm 119.77 \mathrm{mg} / \mathrm{dl}$ whereas in the control group it was $323.60 \pm 73.16 \mathrm{mg} / \mathrm{dl}(\mathrm{t}=7.09$ and $\mathrm{p}=0.0001)$. Also, the mean fibrinogen level in complicated Type 2 DM was high $450.43 \pm 108.51 \mathrm{mg} / \mathrm{dl}$ as compared to uncomplicated Type 2 DM cases $372.30 \pm 123.78 \mathrm{mg} / \mathrm{dl}(\mathrm{p}=0.0001)$ (Table 1).

Based on $\mathrm{HbAlc}$ values patients were categorized into three groups 5.5-6.8\% (good control), 6.9-7.6\% (fair control) and $>7.6 \%$ (poor control). (Table 2). Mean HbA1c in type 2 total DM cases was found to be $8.02 \pm 1.88 \mathrm{mg} / \mathrm{dl}$ with a range of 5.50-14.50. In uncomplicated DM patients with

\begin{tabular}{llll}
$\begin{array}{l}\text { Table 1: Fibrinogen level in uncomplicated, complicated } \\
\text { diabetic patients } \\
\text { mean fibrinogen values between groups }\end{array}$ \\
$\begin{array}{lccc}\text { Fibrinogen } \\
\text { (mg/d) }\end{array}$ & $\begin{array}{c}\text { Mean } \\
\text { fibrinogen value } \\
\text { Comparison } \\
\text { between groups }\end{array}$ & p-value \\
\hline Uncomplicated & $372.30 \pm 123.78$ & $\begin{array}{c}\text { Uncomplicated Vs } \\
\text { Control Group }\end{array}$ & 0.022 \\
Complicated & $450.43 \pm 108.51$ & $\begin{array}{c}\text { Complicated Vs } \\
\text { Control Group }\end{array}$ & 0.0001 \\
\hline $\begin{array}{l}\text { DM } \\
\text { Group(Total) }\end{array}$ & $422.22 \pm 119.77$ & $\begin{array}{c}\text { Uncomplicated Vs } \\
\text { Complicated }\end{array}$ & 0.0001 \\
\hline Control Group & $323.60 \pm 73.16$ & $\begin{array}{c}\text { DM Group Vs } \\
\text { Control Group* }\end{array}$ & 0.0001 \\
\hline
\end{tabular}


Table 2: Comparison of glycemic control with plasma fibrinogen level in complicated and uncomplicated DM patients

\begin{tabular}{lccc}
\hline DM groups & $\begin{array}{c}\text { Good Control } \\
\text { (HbA1c 5.5-6.8\%) }\end{array}$ & $\begin{array}{c}\text { Fair Control } \\
\text { (HbA1c 6.9-7.6\%) }\end{array}$ & $\begin{array}{c}\text { Poor Control } \\
\text { (HbA1c }>\text { 7.7\%) }\end{array}$ \\
\hline Fibrinogen level in Uncomplicated DM patients & $291.87 \pm 46.50$ & $368.75 \pm 87.24$ & $460 \pm 140.81$ \\
Fibrinogen level in complicated DM patients & $334.37 \pm 48.43$ & $397.69 \pm 59.32$ & $514 \pm 89.14$ \\
\hline t-value & 2.53 & 0.90 & 1.69 \\
p-value & 0.017 & 0.37 & 0.096 \\
\hline
\end{tabular}

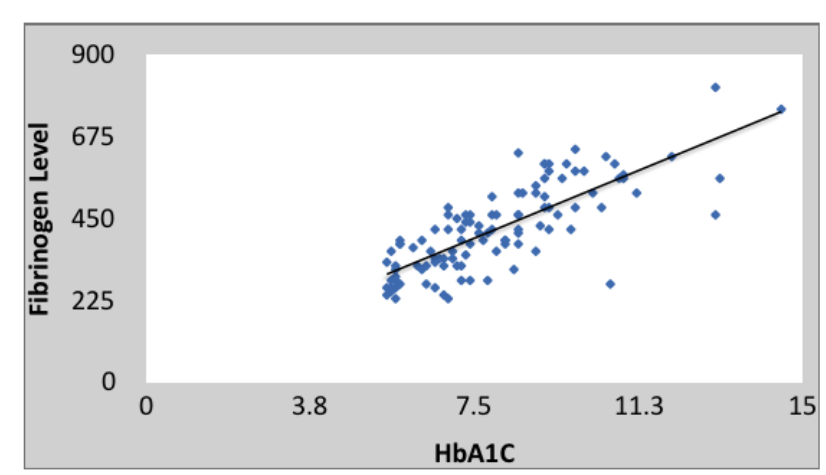

Figure 1: Correlation between HbAlc levels and mean fibrinogen values

good glycemic control, the mean fibrinogen level was $291.87 \pm 46.50 \mathrm{mg} / \mathrm{dl}$ in contrast to $334.37 \pm 48.43 \mathrm{mg} / \mathrm{dl}$ in complicated DM. $(\mathrm{t}=2.53, \mathrm{p}=0.017)$. Statistical correlation between $\mathrm{HbAlc}$ and mean fibrinogen level was found to be significant $(r=0.782, p=0.001)$ (fig. 1$)$

On comparing the duration of diabetes with fibrinogen levels in patients with 10 to 15 years duration, the mean fibrinogen level was found to be a maximum of $502 \pm 142.68$ $\mathrm{mg} / \mathrm{dl}$ as compared with other groups. By using the Pearson coefficient test, a positive correlation was found between the duration of diabetes and mean fibrinogen levels $(\mathrm{r}=0.295$, $\mathrm{p}=0.002$ ). (Table 3 )

\section{DISCUSSION}

DM is a major health problem whose burden is evident in developing countries like India as well. ${ }^{8}$ It is among the top 10 causes of death and was estimated to have caused four million deaths in adults in 2017 worldwide. ${ }^{9}$ In 2019 a total of 7.7 million people (20-79 years) from India are estimated to be living with diabetes. This number is expected to increase to 101 million $(10.2 \%)$ in 2030 and 134 million (10.9\%) in 2045. Currently, nearly half (50.1\%) of people with diabetes do not even know that they have diabetes. ${ }^{2}$ For the past two decades; irrespective of the type of DM, hemostatic factors especially fibrinogen has been considered as an independent risk factor for atherosclerosis and its complications like; MI, stroke, angina, etc. ${ }^{10}$

The mean age of patients for uncomplicated Type $2 \mathrm{DM}$ was $53.58 \pm 11.1$ years, for complicated DM was $57.85 \pm 11.33$ years, and for the control group mean age was $54.33 \pm 12.13$ years. Our findings are consistent with Agarwal $\mathrm{C}$ et al ${ }^{11}$ who found $55.63 \pm 7.49$ years as the mean age for patients with complicated type $2 \mathrm{DM}$. The youngest patient was 35 years old and the eldest was 80 years. The maximum numbers of patients were in the age group of 51-60 years $(30.56 \%)$ followed by $61-70$ years $(29.63 \%)$ and $41-50$ years $(26.85 \%)$. These results are in agreement with a study by Bembde AS in which the maximum number of patients were in the age group $51-70$ years $(69 \%){ }^{12}$

The mean plasma fibrinogen level in total DM cases was found to be high $422.22 \pm 119.77 \mathrm{mg} / \mathrm{dl}$ in contrast to $323.60 \pm 73.16 \mathrm{mg} / \mathrm{dl}$ in the control group and this difference was statistically significant $(\mathrm{p}=0.0001)$. Our findings of high fibrinogen levels in cases of DM were consistent with Bembde $\mathrm{AS}^{12}$, Sapkota B et $\mathrm{al}^{13}$, and Gupta RK et $\mathrm{al}^{14}$.

Also, the mean fibrinogen value was high $450.43 \pm 108.51$ $\mathrm{mg} / \mathrm{dl}$ in complicated cases as compared to $372.30 \pm 123.78$ $\mathrm{mg} / \mathrm{dl}$ in uncomplicated type $2 \mathrm{DM} .^{14,15}$ Thus, we concluded that levels of plasma fibrinogen are associated with the severity of type $2 \mathrm{DM}$.

Hyperfibrinogenemia in DM cases may be related to lowgrade inflammation and elevated cytokines particularly

Table 3: Correlation of duration of DM in years with fibrinogen level

\begin{tabular}{|c|c|c|c|c|c|c|c|}
\hline Duration & No. & $\begin{array}{c}\text { Mean of fibrinoge } \\
n(\mathrm{mg} / \mathrm{dl})\end{array}$ & Std. Deviation & Std. error & F-Value & P-Value & Correlation "r" \\
\hline$<1$ yrs & 15 & 382.66 & 107.40 & 27.73 & 4.52 & 0.002 & $\begin{array}{l}0.295(+\mathrm{ve} \\
\text { correlation) }\end{array}$ \\
\hline 1 to 5 years & 39 & 377.69 & 104.01 & 16.65 & & & \\
\hline 6 to $10 \mathrm{yrs}$ & 29 & 449.65 & 107.12 & 19.89 & & & \\
\hline 11 to $15 \mathrm{yrs}$ & 15 & 502.00 & 118.62 & 37.51 & & & \\
\hline$>15 \mathrm{yrs}$ & 10 & 456.00 & 118.62 & 37.51 & & & \\
\hline Total & 108 & 422.22 & 119.77 & 11.52 & & & \\
\hline
\end{tabular}


interleukin-6 which stimulate hepatocytes to produce fibrinogen, representing an important link between inflammation and hypercoagulation. ${ }^{16}$ Peripheral insulin resistance and hyperglycemia also have a direct impact on fibrinogen levels, whose concentrations are correlated with insulin and pro-insulin levels in healthy subjects also. ${ }^{16}$

In DM hyperfibrinogenemia is a result of a procoagulant state due to an increase in numbers of coagulation factors such as von-Willebrand factor, fibrinogen, plasminogen activator inhibitor 1, factor VII and thrombin antithrombin complexes particularly in association with microvascular and macrovascular complication and glycemic control. ${ }^{17}$

However, the mechanism by which fibrinogen increases the risk of cardiovascular complications is not fully understood. The proposed mechanisms by which hyperfibrinogenemia promote atherosclerosis and thrombus formation are increased plasma viscosity, inflammation and endothelial injury, induction of RBC and platelet aggregation, the formation of fibrinogen degradation products (FDPs) which bind low-density lipoprotein and sequester more fibrinogen and FDPs and fibrinogen stimulate smooth cell proliferation and migration. . $^{12,17}$

Besides, hyperfibrinogenemia was found to be associated with age, smoking, hypertension,

glycemic control, and duration of type 2 DM.18 The glycemic control affects fibrinogen levels, as relative deficiency of insulin in DM, results in differential protein synthesis i.e., a 29\% decrease in albumin synthesis and a $50 \%$ increase in fibrinogen synthesis. Also, glycosylate fibrinogen is less susceptible to plasmin degradation.19

We also studied the correlation of duration of type $2 \mathrm{DM}$ in years and fibrinogen level. Among the patient with DM with 10 to 15 years duration, the mean fibrinogen level was found to maximum $502 \pm 142.68 \mathrm{mg} / \mathrm{dl}$ as compared to patients with lesser duration of DM $(p=0.002)$. Similar observations were made by Gupta RK et al. ${ }^{14}$ However Kafue DR et al ${ }^{15}$ did not find any significant association between the duration of diabetes in years and fibrinogen level.

In present study diabetic patients were categorized into three groups depending upon the HbA1c values i.e., 5.5-6.8\% (good control), 6.9-7.6\% (fair control), and $>7.6 \%$ (poor control). Among 108 DM patients, $29.63 \%$ of patients had good glycemic control, $19.44 \%$ of patients had fair glycemic control and $50.93 \%$ of the patients had poor glycemic control. A high number of diabetic patients (50.93\%) with poor glycemic control in the present study might be due to poor dietary practices and lack of knowledge regarding the diet and exercise regimens that ought to be followed in diabetics. $^{20}$

Mean HbA1c in Type 2 total DM cases was $8.02 \pm 1.88 \%$ with a range of 5.50-14.50 and it correlated significantly with mean fibrinogen level $422.22 \pm 119.77 \mathrm{mg} / \mathrm{dl}$ (with a range of 230-810) in Type 2 total DM. Similar results have been observed by Bemde AS,12 Gupta RK et al,18 and Abdeurahman NM et al. ${ }^{21}$

In the present study, the mean $\mathrm{HbA} 1 \mathrm{c}$ level in uncomplicated type $2 \mathrm{DM}$ cases and complicated Type 2 DM cases were $7.41 \pm 1.78 \%$ and $8.37 \pm 1.89 \%$ respectively, and this difference was statistically significant $(p=0.001)$. The studies conducted by Mohan $\mathrm{V}$ et $\mathrm{al}^{22}$ and Gupta RK et $\mathrm{al}^{14}$ reported that the mean $\mathrm{HbA1c}$ level was high in patients with complicated DM. Mohan V et $\mathrm{al}^{22}$ also concluded that the prevalence of both macrovascular and microvascular complications was high due to poor glycemic control.

Poor glycaemic control may lead to hypercoagulability because glucose causes a direct effect on the endothelium. Long-term hyperglycemia damages the endothelium by increasing glycosylation of proteins and lipids to form advanced glycation end products. 23 Glycemic control in Indian diabetic patients is poor which has resulted in high morbidity and mortality associated with diabetic complications. However, in our study mean $\mathrm{HbA} 1 \mathrm{c}$ value in total DM cases was $8.02 \pm 1.88 \%$ which was lower than that in a study by Mohan V et al22 (9.2\% in 20,554 patients of Type $2 \mathrm{DM}$ ). This difference is due to the small number of patients in our study. A significant positive correlation exists between age, duration of DM in years, plasma fibrinogen levels, and $\mathrm{HbA} 1 \mathrm{c}$.

\section{CONCLUSIONS}

Plasma fibrinogen levels are elevated in type 2 DM and this elevation was associated with poor glycemic control as evidenced by increased HbA1c levels. The other parameters which correlated with plasma fibrinogen levels were age and duration of DM in years. The patients in the 60-70 years of age group and having a history of DM for 10-15 years had higher fibrinogen levels compared to younger patients. Thus, lowering plasma fibrinogen levels could be an important approach to the prevention of cardiovascular complications in DM.

\section{Conflict of interest: None}

\section{REFERENCES}

1. Jain R, Jain P, Jain P. A review on treatment and prevention of diabetes mellitus. Int J Curr Pharm Res 2016;8:16-8. Website

2. Saeedi P, Petersohn I, Salpea P, et al. Global and regional diabetes prevalence estimates for 2019 and projections for 2030 and 2045: Results from the International Diabetes Federation Diabetes Atlas. Diabetes Res Clin Pract 2019;157:107843. Crossref

3. Madan R, Gupta B, Saluja S, Kansr UC, Tripathi BK, Guliani BP. Coagulation profile in diabetes and its association with diabetic microvascular complications. J Assoc Physicians India 2010;58:4814. Website 
4. Abdulrahaman Y, Dallatu MK. Evaluation of prothrombin time and activated partial thromboplastin in patients with diabetes mellitus. Nigerian J Basic Appl Sci 2012;20:60-3. Website

5. Jain A, Gupta H, Narayan S. Hyperfibrinogenemia in patients of diabetes mellitus in relation to glycemic control and urinary albumin excretion rate. J Association Physicians India 2001;49:227-30. Website

6. Dacie JV, Lewis SM. Practical Haematology. 8th edn. Churchill Livingston: London; 1994. pp 305-10.

7. Thomas L, Thomas C. Evidence-based laboratory medicine. Clin Lab 2001;47:479-82. Website

8. Mitra S. Diabetes research, prevalence, and intervention in India. Eur J Environ Public Health 2019;3:em0023. Crossref

9. International Diabetes Federation. IDF 8thedn. Brussels, Belgium; 2017. Website

10. Mohiuddin SS. Correlation of glycemic status with plasma fibrinogen level in insulin dependent as well as noninsulin dependent diabetic patients. J Endocrinol Diab 2018;5: 1-6. Crossref

11. Agarwal C, Bansal K, Pujani M, et al. Association of coagulation profile with microvascular complications and glycemic control in type 2 diabetes mellitus- a study at a tertiary care centre in Delhi. Hematol Transfuse Cell Ther 2019:41;31-6. Crossref

12. Bembde AS. A study of plasma fibrinogen level in Type-2 Diabetes mellitus and its relation to glycemic control. Indian J Hematol Blood Transfus 2012;28:105-8. Crossref

13. Sapkota B, Shrestha SK, Poudel S. Association of activated partial thromboplastin time and fibrinogen level in patients with type II diabetes mellitus. BMC Res Notes 2013;6:485. $\underline{\text { Crossref }}$
14. Gupta RK, Dhawale S. Association between serum fibrinogen level in Type-2 Diabetes mellitus patient with or without microvascular complication. IJAR 2015;1:555-61. Website

15. Kafle DR, Shrestha P. Study of fibrinogen in patients with diabetes mellitus. Nepal Med Coll J 2010;12:34-7. Website

16. Pomero F, Di Minno MN, Fenoglio L, Gianni M, Ageno W, Dentali F. Is diabetes a hypercoagulable state? A critical appraisal. Acta Diabetol 2015;52:1007-16. Crossref

17. Mohan A, Srinivasan V, Deepa R, Mohan V. Lipoprotein (a): role in diabetes and its vascular complications. JAPI 2001;49:1100-5. $\underline{\text { Website }}$

18. Brownlee M, Ulassara H, Cerami A. Nonenzymatic glycosylation reduces the susceptibility of fibrin to degradation by plasmin. Diabetes 1983;32:680-4. Crossref

19. Pierpaola DF, Margaret GG, Haymond MW. Differential effects of insulin deficiency on albumin and fibrinogen synthesis in humans. J Clin Invest 1991;88:833-40. Crossref

20. Kodiatte TA, Manikyam UK, Rao SB, et al. Mean platelet volume in Type 2 diabetes mellitus. J Lab Physicians 2012;4:5-9. Crossref

21. Abdeurahman NM, Ali EW. Correlation between glycemic control and plasma fibrinogen level in patients with Type2 Diabetes mellitus. Lab Med J 2013;1:16-22. Website

22. Mohan V, Shah S, Saboo B. Current glycemic status and diabetes related complications among type 2 diabetes patients in India: data from the Alchieve study. J Assoc Physicians India 2013;61:12-5. Website

23. Santilli F, Vazzana N, Bucciarelli LG, Davì G. Soluble forms of RAGE in human diseases: clinical and therapeutical implications. Curr Med Chem 2009;16:940-52. Crossref 